要であることなどが主張された.そしてこれらはいず れも現実にはきわめて困難なことがらであり，しかも， そらして得られた分布も normal curve にならないる のが多いため, 確率限界測定值が計算できない。この 点でさらに非ガウス的分布についても研究をすすめる ことが要求されるというものであった.

これについて, 木村 (日大) は, 身体的なものが normal curve しやすいのに対し, 心理的なものはそう なりにくいのは当然であろらと述へ，また柏木（東洋 大）は，従来つかわれてきている normal curve はあく まで仮説上のものであり, 心理的な現象そのものが normal curve をすることを必ずしも意味していない。 現象が normal curve しないからといって, 測定がで きないということはないのではないかとの意見を述べ た.

下山・曽我部の研究は, 坚童・生徒の行動とこれら の動機づけとの関連を明らかにするための第一段階と して行われたもので, 達成・親和動機つけけの測定に関 するものであった. この中の因子分析について柏木(東 洋大）は, rotate された場合の各因子群の相関の二乗 和は eigen value とはいわないと指摘し, (Table 1), おそらくこの分析は 2 3 因子についてのみで十分で ないか，また発見された性差についても，それを点数 上の差異と見なすか構造上の差異と見なすかといら問 題があるのではないかと述べた. 田中（信州大）は, 達成・親和の測度と sociometric 尺度である CRS と の間に関係が見出せなかったことについて，CRSは， 学級内での社会的行為に対する相互評価であり, 達 成・親和の欲求が強くても, それが学級集団内で受容 されない場合もあるから，必ずしも相関は期待されな いのではないかと指摘した。

木村の研究は, マズロ一の欲求発達の 5 段階説をも とに 35 項目の（価値観尺度を作成し，之れらを被験者 （大学生）にQ Q分類させるという方法についての報告 であるが，討論の方向は，むしろ測定された結果と現 代青年の理解の仕方との関係に向けられた. 特に, 討 議希望事項 2 で現代青年が宗教とか哲学には興味を示 さず生理的欲求とか愛の欲求に強い関心をもつのは,
心の安定を欠いているためではないかといら解积に中 いて，心の不安定性が宗教や哲学に興味をすたせな い原因であるといら結論は性急すぎやしないか，青年 はたしかに，不安や緊張を持っているが，それが宗教 や哲学に向かわないといらところに問題があるので あって，そこをもっと検討すべきではなからうかとい ら意見が述べられた。

木津川の研究は, 断片的な線を一筆書のできる形に つなぐ作業をテストとし、て実施し，それらの結果と学 カ・知能との関連を調査したものであるが,これらは, 初期には描画テストから類推して性格との関連が予想 されたものであるとの補足的説明があった. 下山（学 芸大）は，このテストが何の心理測度となりうるのか といら疑問を出したが，これに対して，発表者は，他 の幾何学的図形や事物の略画を用いたテストと本テス トでは結果にちがいがあるので，この差をどう解釈す るかが問題であり, 今後追求していかなければならな いと述べた。

辻西の研究は, 現在作成中の就学児標準知能検査の 下位項目の1つである「絵さがし」についての分析で あるが, 討議希望事項の 1 について, このテスト項目 は目的にそわなかったので他の材料を求めているのか はっきりしないとの疑問が出された。これに対し，発 表者は, 今回の材料は一応上かったと思うが，もっと 子どもたちが興味をもってよろこんでとりくむものを 考えていかなければならないと回答した。

拖尾の発表は, 5 段階評定や 7 段階評定で態度や興 味を自己評定するときにあらわれる中心化傾向や寬大 化傾向を，因子分析の過程で除去していく方法につい てのものであった。 また, 田中の研究は, Sociometric

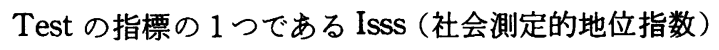
の評価法についてのものであったが，発表者から，標 本が思らように集まらない場合，確率的な分布を土台 として，実現値を評価していくという方法についての 是非が問題として提起された。

なお，記録者の不手際から討論者の所属・氏名の不 明なるのがあったことをおわびする.

（田中祐次 記）

\title{
臨床・障害（801～808）
}

座長 原 野 広太郎・今 井 靖 親

801 暗示療法を中心にした夜尿児治療の一試み (1)
埼玉県与野市教育センター ○福 島 春 生 埼玉大学 茨木 俊夫 埼玉県立教育センター 金子保 
802 恐怖症・不安神経症の生理心理的反応 (1) 一反応の比較研究—

$\begin{array}{crrr}\text { 東京教育大学 } & \text { ○小 } & \text { 玉 } & \text { 正 博 } \\ " \prime & \text { 原 } & \text { 野 } \text { 広太郎 } \\ \prime \prime & \text { 沢 } & \text { 崎 達 夫 }\end{array}$

803 情動反応の観察学習におけるモデリング効果

筑波大学 ○山 口 正二 東京教育大学 小 玉 正 博

原 野 厷太郎

804 動物恐怖除去におけるモデリングの効果

奈良教育大学 今 井 靖 親

805 慢性精神分裂病患者の言語条件つけに関する研

究

東京教育大学 今 野 義 孝

806 Scaring Methodによる暗示効果の研究

教育診療室 重 倉 孝 順

807 HYPERACTIVE CHILD の行動変容について

静岡県西部児童相談所 $\bigcirc$ 福 永 博 文 静岡大学 林 邦 雄

808 一男性強迫神経症患者の治療経過について

$$
\text { 佐賀大学 中山 媵 }
$$

\section{I 討論の経過}

801 （福島ら）に対して, 亀倉（教育診療室）から, 対象児の症状の度合はどの程度か，また重度の case については, どのような treatmentを行っているかと いう質問が出された，福島は，症状には月に何回，週 に何回，毎晚などの段階が考えられるが，本研究では 主に週 3〜4 回の者を対象としている. 毎晚（亀倉のい ら夜尿度 1）といらような重症児にはプレイセラピー も併用しているといら主旨の回答を行った。

803 (山口ら) に対しては, 鈴木（早大）から, 代理 経験 verbal 群の被験者に対する feed back は何に よって生じたと考えているかとの質問が出された。山 口は，単に目で見ただけで生じたのか，言語によって 生じたのか不明だが, 我々は言語の意味によって生じ たと考えていると述べた。さらに鈴木から，物理的刺 激によっても容積脈波における振幅の減少が予想され るが，これとモデル刺激による情動状態を伝える反応 との差異を区別するために, 何らかの統制群が必要で はないかとの意見が出された。

804 (今井) に対しては, 倉光（京大）より, この実 験に関連して，他者が自分とあまりにも異なると感じ た場合には,「あの人はこわがらずに平気でいるのに, 自分はこわい, だめだ……といら気持が強まって, モデルの存在がかえって这効果をもたらすことも考え
られないか, といら主旨の質問が出された。今井は, 確かにそのようなモデルに対する他者認知が観察者の 行動に影邦を及ぼすことが考えられると回答した。

805 (今野) の発表に対しては，まず小玉 (東京教育 大）より, 反応曲線の変化を言語条件づけ場面に拈け るコントロールの結果として考えるのか, それともク ライェントの病態の変化あるいは他の生活指導などの 関連においてとらえるのか，といら質問が出された。 今野は，その分析は困難だが，現段階では前者をより ドミナントに考えていると答えた。 また，今井（奈良 教育大）より，知能の向上が見られたとの報告があっ たが，いかなる原因によると考えているのか，という 質問があった. 今野は，これは言語条件づけにおける， 話すことによる効果であると考えていると答えた。さ らに原野（東京教育大）より，(1)「うん，らん」や「な るほど」を強化因として用いること (2) TAT の課題を conditioning の index として用いることに疑問が出 された。これに対し，今野は「らん，らん」などが強 化になっているのか, それともクライェントといっ しょにいる事態そのものが強化になっているのかは不 明である. 今後, 強化因の気づき方の測定を敩密に行 ら必要があると考えていると回答した。

806 (亀倉) の発表に対しては, 小玉（東京教育大） から, scaringに用いた器具のメカニックは何か, また その生理学的意味は何かとの質問がなされた。亀倉は, 器機によって与えられる視覚的・聴覚的な刺激は, ク ライェントに自分の障害や症状の実態あるいは症状の 程度を認識させるための合理的ならそであり，一種の 治療テクニックであると答えた。 さらに小玉から, 器 機を使用するから物理療法だとは思わない，Biosocial あるいはPsycho-social な関係から治療を考 えていこらとしている理論的根拠は何かとの質問が出 された，これに対して，亀倉は，来室するクライェン トにはPsycho-social または Bio-social な原因によ る疾患が多いので, 治療効果をあげるために器機を用 いた視聴覚的な scaring を導入している，という要旨 の回答を行った.

807 (福永) の報告に対し, 今井（奈良教育大）から は, 強化呈示の合図としてブザーを使用しているが, メロディのほうがより効果的ではないか, また今野(東 京教育大）からは, affective な言語（たとえば「よく できたね」)といっしょに強化を与えたほうが、ことば の持つ情緒的な面もいっしょに学習できてよいのでは ないか, との疑問が出された。これに対し, 金光（京 大）からは, novelty といら観点からすれば, ブザー でよいと考えるとの意見が出された．金子（埼玉県立 
教育センター）は，(1「毒親へのカウンセリングは有 効ではなかった」との報告は早急な結論ではないか (2) このようなオペラント条件づけは，事例によっては全 人格的発達にとってマイナスである場合も考えられる が,この点に関していかなる配慮をもってのぞんだか， という質問を行った。福永は (1)に対しては，母親への カウンセリングは他のセラピストが行ったものである が, 全く無効だったとは考えていない。(2)に対しては, このアプローチでは，多動そのものを抑えることを目 的とはしていない，クライェントの興味あるものを強 化し，症状を軽減させていくようにした，との回答を 行った.

808 (中山) の発表に対し, 中里（山梨日下部病院）は, (1)この症例の症状, 入退院の時期, 基本的問題など (2) 治療者の立場，面接以外の治療方法について説明を求 めた. 中山は (1)については, 父親における権威ある男 性のイメージの欠如と，母親の過保護とが発病の機制 に関連があると考える，(2)については，受容的，支持 的であるが，少なくとも精神分析的立場ではなく，心 理劇，集団療法なども併用している，と答えた。

\section{II と め}

この部会は, プログラム編成に際して, 主として行
動療法に関連のある研究をひとまとめにしたるのと思 われるが，時間的な制約もあって，十分な討議ができ たとは言いがたい，質疑・応答や討議は，ほとんど発 表者または共同研究者の間でなされ，フロアからは， わずかに 3 人が参加したのみであった. 802 (小玉ら) の研究は, 恐怖症と不安神経症に批いて, 不安反応に 差異があることに着目して，言語刺激による情動イ メージとそれに伴なら生理的変化とを, 主としてプレ ティスモグラフを用いてとらえ，その特徴を明らかに したものである。803，805 とも関連があったので，ぜ ひ討議の対象としてとりあげてほしかったと思う.

可能であったなら，例えば，804，805，806，807に 共通して関連性のある,「強化の方法は適切であったか どらか」といらような問題について，つっこんだ検討 を行ってみたかった. しかし，最初に述べたように， この部会には行動療法に関連のある研究が集められて いたとは言え, 同じく行動㞠法の範疇に入るもので も，基礎的・実験的な研究もあれば，具体的・実際的 な治療方法の検討を目的とした研究もあったうえ，治 療理論やアプローチの方法が全く異なった研究も含ま れていたため，限られた時間の中で一括した討議を進 めることは困難であった。

（今井靖親）

\section{臨床・障害（809～815）}

座長斉藤繁・岡田明

809 特殊学級における就学諸問題について

埼玉県大里郡川本中学校 小久保隆 福

810 精神薄弱児に対するオペラント技法における強 化因子価の比較 (8)

東京都東村山福祉園 鈴 村 健 治

811 精神薄弱児の内発的動機づけに関する一実験的 検討

早稲田大学 阿 部 健一

812 精神遅滞児の言語行動の研究XI 一意図的 学習と偶発的学習における教示と刺激材料の効 果一

弘前大学 斎 藤繁

813 精神遅滞児における外的指南性と弁別学習の関 連性をめぐって
814 弱視児の漢字の読みの学習に関する一実験

筑波大学 岡田明

815 盲・ろう・精薄三重障害児の異常習癖に関する

事例研究

一続報一

国立特殊教育総合研究所田口則良

\section{I 発表と討論の経過}

小久保の研究 (809）は，障害児教育の臨床での主 要な問題点を指摘し，担任教師の資質や教育観につい て考察したものである. 岡田（筑波大）は，子どもの 幸せ, integrationの意味について專ねた。これに対し て，子どもの劣等感をとり除くこと，入級時に格別な 配慮を怠らない様にすること, 安易に普通学級に所属 させるだけでは問題解決にならないこと等が述べられ た. 更に, 沼尾（国立秩父学園）から，子どもは普通 学級で幸せになれるのかと問われたのに対して，教師 
は社会への適応を考えて教育しようとしているが，特 殊学級内ではどうしても過保護になり,甘やかされる. それで, 結果的には社会に出てから問題を起し易くな ると述べた。

田口の研究 (815) は, 盲・ろう・精薄三重障害児の 異常習癖に関する 1 事例を報告した。岡田は, 異常習 癖とは何をさしているのかと質した．これに対して， この子の発達にとってマイナスになる様な癖を意味す るとの回答がなされた，更に，岡田は，異常習癖は感 情不安定が問題であり, 眼の中に手を入れるとかはさ む行動はBlindism であって，情緒不安定を示すとは 考えられないとの意見を述べた．田中は，手を振る行 動などは，それに当ると打もらが，他に，自己刺激化 や探索的なもの, 情緒不安の解消などが考えられると した，沼尾は，異常習癖に生産的意味合いがあるのか と質したが，触覚をたのしむといらことが目立ってみ られる，例えば，テスト 8 の触覚テストでは，細ペー パーが適当な様で，現在使用している刺激に近縁の刺 激を用いながら点字教育に結びつけてゆきたいと回答 された。

鈴村の研究 (810) は, 精神薄弱児を対象にしたオぺ ラント技法における強化の因子価を扱い，中性刺激を 陽性化する方法を検討した，岡田は，二次強化と発達 年龄との関係を問い，低年龄では，食物でないと条件 ゔけが困難になるとの回答がなされた.

藤本（香川大）は，仮性二次強化の意味之得点分布 の範囲が 0 から 48 にひろがっている事から, 群平均值 で扱うのは問題があり，データ処理において個別的な 標本分析が妥当ではないかと質した。これに対して， 仮性二次強化の呼称は, 中性刺激が常に必ずしも二次 強化価を帯びるとは仮定されないためと述べ，また， この種の実験ではいつも個人差がつきまうが，群と してまとめてみることも必要であると回答された. 田 口は，表 IV の SD が大きすぎ正規分布していない様 であり， $\mathrm{t}$ テストを使用している事に疑義があるとし たが, ウルチの法で検討したとの回答がなされた.

阿部の研究 (811) は, 精神薄弱児の内発的動機づけ を検討した. Ziglerらの研究との関連において, Effective motivation の一成分として mastery motivationを仮定しながら，課題としてWAISのブロッ クデザインテストと三選択肢弁別課題を与え，作業持 続時間とパターン反応の成績を測度とした．結果は普 通児群と精薄児群間に有意な差はなく, 両測度間の相 関は精薄児群に明瞭に認められた。田口（国立特殊教 育総合研究所) は, 課題と mastery motivation との関 連の説明を求め, 更に, 2 つの課題間に相関があった事
でそその様なモチベーションが働いていたといえるか どうかを質した，そして，更に課題解決のプロセスを 扱ら必要があると思らとの意見を述べた．阿部は，前 者については, 操作的定義の形で仮定していると述へ， 対象が精神薄弱児であることから，解決困難な弁別課 題に従事している時間測度を問題にしたと回答した. 関連して, 斎藤（弘前大）から，測度を多くして多角 分析を試みた方が，よりよく主題が生かされてくるの ではないかとの意見も述べられた。

今野の研究 (813) は, 精神遅滞児の外的指南性 (外 的手掛りへの過度の依存性）と三選択肢弁別学習の関 連性を検討したものである. 結果は, 正常児群, 遅滞 児群間で，既存の概念的手掛り利用の能力に差異がな され，後者においてその傾向がより強いと示唆された。 阿部（早稲田大）は, 被験児の所属（施設, 在宅）に よって動機づけの差を生じることから，この問題の扱 いについて質問し，小久保（川本中）からは，実験結 果と日常生活や実際指導との係わり合いについて質問 があった.これに対して，養護学校児童を対象にした こと, 又, この様な実験研究を通して, 教授活動での 原理の発見や児童にきまりなどの理解をさせる為の手 だて，指導の基礎的方法論が見出される事になるだろ ら等の応答がなされた.

斎藤の研究 (812) は，精神遅滞児の偶発的学習を問 題とし, Postman の教示と分化反応との関係について の仮説の検討を行い, 偶発学習効率と教示並びに材料 の感情価の違いによる効果は確証されなかったと報告 した. 阿部が刺激カードの選択基準について質したの に対して,このシリーズの最初の研究で検討している. 材料の熟知価を中心に扱い, 音韻連想価や音節数をコ ントロールし, 絵画化し易いものが条件であると回答 された。

岡田の研究 (814) は, 弱視児の漢字の読みの学習を 検討したもので, 音読の誤りの分析や読書力の多変量 解析から，漢字の読みに問題をもっていることが明ら かになったので，画数の多少，象形文字を付した場合 について吟味した. 象形文字が distractive stimulus になっていないこと. 画数が多いことが, legibilityを 低下させると云われているが，やや学習に影響してい ることが認められる．訓練は学習を促進すると云える と報告された。

\section{II ま と}

本部門での報告は，実験的研究が主体となっていた が, 小久保の発表は, 教育臨床での主要問題の提起と なっていて, やや心理学的研究から逸脱した内容を成 
していた様におるわれるが，質疑応答の方は，文字通 り教育心理学的問題に関して, 真正面から討議する形 となって有意義であった．基礎的実験研究の内容を成 すものは, 阿部 (早稲田大), 今野 (東北大), 斎藤 (弘 前大）の研究であり, 臨床的実験研究としての意義を 有するものは, 鈴村 (東京都東村山福祉園), 岡田 (筑
波大), 田口（国立特殊教育総合研究所）の研究であっ たと云えるだろう。実験研究と実践の谷間を埋めつく すことは, 容易な業ではないとしても, これが本部会 参加者が，ひとしく脳裡に描いていた共通主題であっ たことに変りがないとおるわれる。

（岡田 明・斎藤 繁）

\section{郜床・障害（816～823）}

座長 後藤 秀 爾・隝 田征子

816 自閉児の集団適応に関する研究 (4)

名古屋大学 後 藤 秀 爾

817 自閉児の集団適応に関する研究 (5)

愛知教育大学 細 野 純 子

818 自閉児の集団適応に関する研究 (6)

愛知教育大学 神 野 秀 雄

819 自閉児の集団適応に関する研究 (7)

\begin{tabular}{|c|c|c|c|}
\hline 名古屋大学 & ○陰 & 山 & 英 \\
\hline " & 丸 & 井 & 文 \\
\hline " & 伊 & 藤 & 義 \\
\hline "I & 譲 & & 互 \\
\hline " & 内 & 田 & 一 \\
\hline " & 加 & 納 & 敏 \\
\hline 名古屋学院大学 & 生 & 越 & 幸 \\
\hline 静岡東病院 & 山 & 田 & 厷 \\
\hline 知県コロ & 水 & 野 & \\
\hline 䇤 & & 築 & \\
\hline
\end{tabular}

820 校内通級制による自閉的傾向児の治療教育 (1)

一多動なA児の事例を通して一

宇都宮市立今泉小学校 下 司 昌一

821 情緒障害児に関する研究

一情緒発達過程の側面から一

名古屋大学 譲 西 賢

822 一行動問題児の行動変容について（その 4)

一モデリング商用による初対面者との対話行動の 改善—

東京学芸大学 ○隝 田 征子 岐阜大学 伊藤 秀子

823 緘黙児に対する行動療法的接近の試み（その 1)

ーテープレコーダーを使って一

武蔵野市教育相談所 ○井 原 成 男

早稲田大学 大上良 隆

\section{I 発表と討論の経過}

この部会での発表は, 自閉児の治療教育に関する研 究 (816 819，820）と, 何らかの意味での情緒障害児 に対する治療的接近に関する研究 $(821,822,823)$ と に分けられた，討議はこの 2 つの主題にそってすすめ られたが，結果的には，各々の発表に対する個別の質 疑応答以上には展開し得なかった. 各々の研究の背景 を理解するための質問が専らであった.

816 819 は, 自閉児の普通学級への適応の過程を検 討した一連の研究である. 一昨年度の発表になる先の 探索的研究からの展開である旨の説明がなされ, NAGA と NAUDS の両評定スケール及び結果の補足 が資料として配布された. その NAUDS の評定に関す る質問が曾我（兵庫医大）より出され, 险山から, NAUDS は本来, 遊戯治療場面で症児と実際に関って いる担当者によって評定されることを想定しており， 臨床的な自を重要視していること, 従って, 評定のた めの学習を行った上で, 通常は合議の下で評定がなさ れるなど, 主観性の排除にも留意している点が説明さ れた. 角張 (精神医学研究所) からは, この研究の背 景とオリェンテーションについて多岐にわたる質問が 出されたが，次の 4 点にまとめて回答がなされた，1) えているのかとの問には，丸井から，普通学級が望ま しいといら背景はあるが，事例によって実に多様であ ク，結論は未だ出し得ていないとの説明がなされた。

2）遊戯治療と集団との位置づけに関する問題では, 蔭 山より, 学校, 治療場面, 家庭, 地域などにはそれぞ れの意味と位置づけがあり, 各々の体験が統合されて いくことが必要であろうとして, 対人関係の基盤を 作っていくような治療システムを考えている旨の具体 的な説明がなされた，3）自閉児の認知能力に関する 問題については，対人関係障害を基本的なものとして 考えているが, 全ての症児が認知能力の障害をもって 
いるとの捉え方が，神野によって確認された。 また丸 井より, 従来の診断規準にこだわらず症児の発達経過 を見直す中で新しい類型を考えていこらとしていると いら方向性の説明もなされた. 4)この研究でいら I 群の症児の治療教育をどう考えているかといら点につ

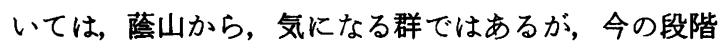
での評価はできないので, 現在すすめている養護学校 等の教師との共同研究の中で再評価していきたいとの 説明がなされた。

820 は，情緒障害児学級で自閉的傾向児と取り組ん できた実践報告であり，スライドを用いて校内通級制 の実態などが説明された。 また NAGA と NAUDSに よる評定結果も示され, 丸井からは, クラスの他の 4 人 の児童に対する指導について, 生越からは, 受け入れ 側普通学級の協力のあり方についての質問が出され た. 前の質問については, 複数担任制を採っており， A児については特に 1 対 1 の指導がなされ，他の 4 人 は今 1 人の教師が指導している状況であること, 後者 については，普通学級担任の配虑により，A児の世話 をする児童をあてるような工夫がなされていることが 説明された。

821 は，いわゆる情緒障害児を情緒発達の観点から 体系づけることを目的とした研究の最初のステップで あることが強調された.これに対し, "情緒表出の体験" あるいは "発達" といら用語の使い方について险山及 び神野から，用語を使う上での妥当性に関して隝田か らそれぞれ質問が出され, 更に都築からは, 対人関係 を問題にするのに児童側の要因のみで考えることにつ いての疑問が出された。それに対し，今回は，児童の 側に焦点を絞って順序性についての仮説を自分なりの 枠組みから構築しょらとしたものであり, 指摘の点は 全て今後の課題としたいとの回答がなされた。

822 は, 器質的障害が疑われ, 対人行動に問題を持つ 発達遅滞児への行動療法的接近が主題とされている が, 丸井から，1）この事例を選んだ理由，2）この事 例で認められた自己評価規準の進歩は何故と考兄られ るかとの質問がなされた，1）については，非指示的遊 戯療法が完了とされたにも拘らず，学校で問題が再発 したとの経過が説明され，2）については, 訓練効果と いらより発達の時期と考えるべきであろうとの回答が なされた，生越からは，治療者一児童関係に関する質
問が出されそれに対し，治療者は積極的に児童にかか わっていき，流動的にプログラムを考え，自分がどう いう操作をしているか判っていることが必要だとの考 え方が, 今後のプログラムの組み方をも含め, 具体的 に説明がなされた。

823 も, 行動療法的接近と題した研究であるが, 生越 から，1）行動療法と言ったところの根拠，2）テープ レコーダーを用いた狙い,及び 3）今後の発展につい ての質問が出された. それに対し，1） "受容"といら ことでは従来の心理治療とかわらないが, 積極的に ルールを学習させるといらことで行動療法と言ってお ク，2）症児に自信をつけさせ,担任の症児に対する評 価を改めることが狙いであったこと，3）単に臨床的 試みとして位置づけているとの回答がなされた，小林

（東教大）からは T-C 関係よりむ，むしろ母子関係を 基盤として対人関係を拡げるような方法は考えられな いかとの疑問が出され，家族の治療参加といら点では 限界も考えられるが，再考してみたいとの回答がなさ れた. 鎌田（東京都心身障害者福祉センター）からは, 治療期間, 具体的手続, 学校・家庭での行動など, 事 実レベルの押えが必要である旨の質問が出され若干の 補足説明がなされた.内田からは, この方法を他の緘黙 児にも適用することについての考えを求められたが， この事例の性格特徵が説明されただけにとどまった。

\section{II まとめと所感}

自閉児の治療教育に関する研究は近年とみに盛んで あり，様々な立場からの議論がなされている．各々の 立場から，よく体系的な知見の提起されることが望ま れている現状であるとの感を深くした．また，他の情 緒障害児についても同様のことが感じられる.ここで の行動療法的接近は, ともに従来の心理治療に対する 批判から出発しているように見受けられる.しかし一 方で, 心理治療法のたてな扎しと体系化を図ろらとす る動さむあるわけで, 情緒障害児を発達的に位置づけ ようとする研究も，そらした志向性からのものである よう理解すべきなのかも知れない.

最後に, 司会の未熟をお詫びすると共に, 参加者の 熱心な討議に感謝の意を表したい.

（後藤秀爾・隝田征子） 


\section{䧗床・障害（824～831）}

座長 内須川洮・若 葉陽子

824 聴覚障害児の言語発達

一機能語の獲得一

東京都心身障害者福祉センター 小田 正 敏 石戸谷 栄 一

825 Maternal Deprivationが疑われる発達遅滞児 の言語行動形成

一その 2. 聴能力促進訓練と発語訓練一

東京学芸大学 若 葉 陽子

827 自閉児の言語に関する研究（第 1 報）

一言語症状観察目録の作成と言語症状の因子分 析一

名古屋大学 内田一成

828 自閉児の言語発達に関する研究

一病理言語と対人関係発達の分析の試み一 名古屋大学 丸 井 文 男 " 蔭 山 英 順 筑波大学. 都築 繁 幸

830 音声言語行動と動作的対応行動について（その2） 東北大学 菅 井 邦 明

831 親子言語関保診断テストの標準化に関する研究 (1)

一再テスト法による信頼度の測定一

大阪教育大学 内須川 洸

\section{I 発衰と封腀の経過}

本部門は言語の障害に関するもの $(824,825,827$, $828,830)$ と, 検査法の開発に関するもの (831) とが あり, 言語をめぐる研究が発表された. 演題の中, 826 と 829 は発表取消となった。

回答発表は発表論文集に基づいてなされたが，その 経過は次の通りである.

小田ら（824）は，聴覚障害児に対して検査を実施し， 機能語（概念内容が漠然としている語や極めて抽象的 な概念しかあらわさない語）の欠落がみられることを 見出しこの改善のために算数学習を行い望ましい結 果が得られたことを報告した。岡田（筑波大）からは その学習方法の具体的内容を知りたい，仲与根（日本 福祉大学）からは教材としてはトピックスの方が効果 があるのではないかなど指導法に関する質問がでた. また，若葉は，算数学習と機能語の獲得の相互関連の メカニズムについてどら考えるかを質問したが，これ
については今後検討を続けて明らかにしたいとのこと であった。

若葉 (825) は, Maternal Deprivation が疑われる男 児に対し行った言語行動形成のための継続的な治療の 内容とそれに伴なら対象児の言語行動の変化について 報告した.これに対し，(1) Maternal Deprivationの 一般的な定義，(2) 初診時の母子分離不能状態と Maternal Deprivation との相互関連 (3) 対象児の行動特 徵のどの点が Maternal Depvivationによるもの，あ るいは脳損傷によるものであるのか (4) 対象児の全体 的発達の様相 (5) 言語訓練に重点をおいた理由 (6) 予 後の見通しなどについて菅井, 丸山から質問が出た.

特に対象児の聴覚反応促進訓練時にみられた絵カード 探索の際に生じたひとりごとを自己内交信と考えられ るのではないかという言及に対し，それは聴覚的 Feed back そのものではないかとの質問が石戸谷から出さ れたが，演者は言語による思考と結びついた自己発 信・自己受信行動を考えているのであるが，今後多数 例の言語獲得過程について観察し検討を続ける必要が あると考えた。

内田 (827) は, 自閉児の言語症状に関して文献検索 を行って観察項目を選定し，この項目を用いた自閉児 125 名の観察結果を統計的に処理したところ，1６の Factor が導出されたので，これを言語症状に関する基 本的特性と仮定したとの報告をした，これに対し，負 荷量の高い項目として 0.330 以上をとった根拠につい て菅井から質問が出た。

都築ら（828）は自閉児の言語発達に関する一連の研

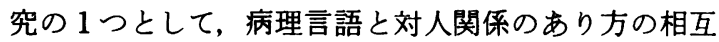
関係について臨床事例 4 例について検討した結果, 次 の 2 点を指摘した。 エュラリアを対人関係発達の指標 としらること, 病理言語に出現順序があり, その内容 から逆に対人関係の深まりを探りらることである。こ れに対し, 内田から, echolalia $\rightarrow$ monologue $\rightarrow$ delayed echolalia は即ち，言語獲得機制にみられる一定の順 序, (外化) $\rightarrow$ (内化) $\rightarrow$ (primitive な統合) に各々あて はめて説明しらるかとの問題が出され，演者は，それ らの機制についてまで検討すべきであると考えている がまだ事例数も少ないので今後の課題としたいと答 えた．若葉は長年言語行動の発達を詳細に追った事例 でみられた言語症状の特徵をあげ，正常言語発達との 差異の検討や echolalia の戦密な定義などの必要性, および話しことばに大きく影響する聴能力の評定の重 
要性を指摘したが, これらの問題については今後の課 題にしたいとのことであった。この他, 倉光 (京都大) からはくり返し言語とェュラリアとの差異の問題など が出された.

菅井 (830) は 1 事例について 2 才 3 か月〜3才 3 か 月まで動作的対応と音声言語行動の対応関係について 観察し, これらの発達過程について考察し, 他からの 刺激に対応して行動する段階から自己が発する刺激 （音声言語・内言）に対応して行動する段階へ移行す ることを報告した。

内須川（831）は標準化の作業過程にある親子言語関 係診断テストを 3〜 5 才の 313 名の幼児母親に実施し, 再テスト法による信頼性を検討し，0.5〜0.6 の信頼性 係数が得られたことを報告した。これに対し，1，2才 児を対象として検討する計画はあるかとの質問が菅井 から出たが，3〜5才児を対象としてこのテストを作製 しているとの答えであった．また，このテストの信頼 性を検討する方法として, 統計的方法を考えているか といら蔭山（名古屋大）の質問に対し，テスト開発の 最終目標は言語障害児に適用することにあるので, 正 常児に実施して統計的に有効な結果が出てもそれのみ では不十分で障害事例に臨床的に適用して検討する必 要があるとのことであった.

\section{II まとめ}

以上, 本部門の発表, 討論では, 言語の障害に関し て, 表層的な現象に留まらず, 障害にみられる種々の Factor の機制に関する話題が多く出された.

従来, 言語 (language) の障害は発達遅滞全般にみ られるものとして論及されてきたが，言語の発達の遅 滞あるいは欠楩は, 正常な言語獲得過程が解明されて いないといら背景もあって, 深く探求されないで過ご
されてきた傾向がある．小田らの研究は聴覚障害児 （者）の言語に対し，その文法的構造のゆがみをとら 交，その欠陥を治療訓練的アプローチで改善すること により,そのゆがみの生じるメカニズムに逆に接近し らる可能性を示唆している. 今後の詳細な発達心理学 的研究により, 聴覚障害における言語能力の実態を明 らかにしていくことが期待される.

次に Maternal Deprivation の問題は，近年日本の 社会でも発生数が増しつつあるといわれているが, 一 事例の報告であるので，言語の獲得の過程では母子関 係が重要であるとの指摘を逆の方向から明らかにする ためにも，多数例での比較検討が必要であろう.

また，自閉児の言語の問題は，いわゆる自閉症の原 因が解明されていない現段階では，その解明にも寄与 することが期待される方途として重要な研究領域であ る. 地道な詳細な検討が重ねられはじめており, 今後 の発展を期待したい.

発達初期にみられる音声言語行動と動作的対応の問 題は, 近年 non-verbal communication として人類学 や生態学的研究方法で追求されるようになってきた人 間の音声言語以外の媒体を用いる communication に 着目するものであり，前述の研究領域の成果を組み入 れた更に詳細な研究が望まれる.

親子言語関係テストの標準化に関する研究は，その 最終目標は臨床場面での言語障害児への適用にあり， 即ち言語障害の予防衛生にも結びつくものとして息の 長い研究が続けられることを望みたい。

以上，各演題をみると，それぞれ対象とする問題は 異なりながらも, 言語の獲得, あるいは言語の獲得の 障害のメカニズムに一歩踏みこんだ研究の動向が印象 としては同える.

（若葉陽子, 内須川洸）

\section{臨床・障害（832～839）}

座長 有 田モト子・氏 原寛

832 ・ 833 中学・高校における登校拒否生徒の指導 に関する研究

関東学院六浦高等学校 ○有 田 モト子 ○松 沢 啓子 関東学院高等学校橋 本 幸 晴 里 村 澄子
834 登校拒否児の訪問面接

$\begin{array}{crcc}\text { 東京都立教育研究所 } & \text { 平 } & \text { 尾 } & \text { 美生子 } \\ " \prime & \text { 佐 } & \text { 賀 } & \text { 明 子 } \\ " & \text { 能 谷 } \text { 尚 子 } \\ \text { 練馬中学校 } & \text { 平 野 } \text { 正 敏 }\end{array}$

835 登校拒否女子中学生とのカウンセリング（その 2)

大阪外国語大学 氏 原寛 836 登校拒否児の予後経過 
一収容治療の順調事例と再拒否事例との対比か ら-

837 登校拒否の考察

$$
\text { 大阪教育大学 岡 林 春 雄 }
$$

一親の生育過程についての一分析一

$$
\text { 大内病院山内常 博 }
$$

838 発表取消

839 学級不適応児の指導例

$\begin{array}{rrrrr}\text { 西堀小学校 } & \text { 金 } & \text { 幸 } & \text { 江 } \\ \text { 東京家政大学 } & \text { 橋 } & \text { 口 } & \text { 英 } & \text { 俊 }\end{array}$

\section{I 発表と討論の経過}

838 が発表取消になったほかは，各発表はいずれも ほほ論文集にそって行われた. 討論には 50 名以上（発 表者も含む）が参加し，個々の発表に対する質疑や意 見と，それに対する発表者の応答の形式が主となって 活発な討論が展開された. 規定の発表時間においても 質問が多く出されたが，その内容については討論のと ころで合せて述べることにする.

発表の経過: 有田, 松沢 (832，833） らは, 登校拒 否に対する正しい理解を深めるため, 登校拒否に関す る文献研究を行った. その結果, 学校に拈ける指導治 療の方法や効果にふれた研究が殆どないことに気づ き, 実態調査をすることによって, 現在, 中学・高校 において登校拒否児に対してどのような働きかけがな されているか実態を把握し, 学校における指導の対策 を考察した.

平尾（834）は，来談しなかった登校拒否中学・高校 生 23 事例に訪問面接をし, 訪問の意味, 訪問の準備, 訪問開始時状況, 訪問後の経過を分析検討し, 訪問面 接の類型化を行った。

氏原（835）は, 昨年度の発表に引続き，不登校を主 訴として，来談し，現在もなお継続中のヶースが，現 段階では単に登校拒否といらよりはもっと大きいコン テクスト，つまり，女性に批る男性とのとり入れと して考えているとの説明があった.

岡村 (836) は, 収容治療を施した 2 事例の登校拒否 児の予後を追求し，予後良好のケースと，予後不良の ケースを対比して報告した。

山内（837）は，登校拒否児をらみだしている親の養 育態度や人䅂の問題点之親自身の生育過程を, さらに, その両者の関連性を分析的に検討した. (山内論文 $\mathrm{p}$. 698 左, 事例一覧No. 3 「拒」を「距」に訂正)

金子（839）は, 小学校入学以来, 学級の集団活動に 適応できない児童の指導例を報告した.

討論の経過: 有田, 松沢の発表に対して, 平田（都
研）は「学校以外のみた原因」は学校側が記入したの か, それとも学校以外のものが記入したのかと質問し た.これに対しては被調査者の生徒指導担当教師が記 入しているとの説明があった．亀倉（教育診療室）は 登校拒否の原因をみると「学校での教師との問題」が 低率でありすぎること疑問があると述へ，学校側で はどらしても「神経症」として判断し, 教師自体にも問 題があることを回避する傾向があるのではないか，ま た，このような調査においては，文部省の基本調査に おける「学校嫌い」の数值とクリニックと演者の $3 つ$ の側面からの調査でないと信ぴょら性が極めてうすく なりはしないかと意見が出された. 山根（文教大）か らの (1) 学校カウンセラー制度の設置を考えた場合, 現 状では多くの困難があるが，いかなる対策が考えられ るか, (2) 公的相談所の機能は現状に即応できると考 えられるかとの問に対して，(1)現状ではカウンセ ラーの資格をもったものがその任にあたっている学校 は殆どないが，養護教諭がそれに近い働きができる立 場にあると思われるがどうか，(2)学校の中では取り 扱劣る問題の範囲が限られるので公立相談機関との協 力を密にしたい. しかし, 公立機関の内容を十分理解 していないので，関係者から意見をきかせてほしいと 発表者からの要望が出された。これを受けて, 山城（静 岡精神衛生センター) は, 養護教諭と学校カウンセラー を同一とするものではないが，現状では養護教諭は近 い距離にあり，また養護教諭の中にも経験者もいるの で, 心身ともに保健衛生といら面で精神衛生面を取り あげてもらら必要がある．そのためにも現任訓練をす る必要があると述べた。越野（浦和精薄更生相談所） は養護教諭と担任教師との関係が密接でない現状で は, 養護教諭の質的な問題だけでなく，機能的な面で も彼らにカウンセラー的働きを期待することは困難で ある. 一般教師のカウンセリングへの理解を深め, 研 究を積み重ねていく機会をもつ必要があると述べた. 中原（茨城大）も，養護教諭や特定のセンターに治療 を依存する考え方には問題がある。教育現場における 各教師一人一人の関心, 認識を高めることが大切だと のべ, 茨城大学では, 教育相談室が主催して開放講座 をもち，現場教師の直面しているさまざまなケースを とりあげ, 専門機関との協力のもとに研究している例 を示された。倉智（大阪教育大）は，登校拒否児の発 生は学校や学級, あるいは教師そのものの側にも大き な問題がある. したがって, 拒否児の指導に当っては, 単に特定の教師 (ex. 養護教諭)だけの関心だけではな く, 教師全体の強い関心がなくては真の治療や指導に はつながらないのではないか。学校カウンセラーの制 
度が確立されるまでは，現状では，担任教師を中心に， 教師全体の連絡と討議が必要であるとのべた。これま での討議をまとめるかたちで，堀（日本福祉大）は, もし，学校が子どもたちにとって真の生活の場になっ ているなら，簡単に逃避できないはずである，新入園 児, 新入学児は新しい場になれるために大変な努力を している.これは，「よそ」を「らち化」することの努 力である，家庭む，学校もこの事態に十分注意をむけ ることが必要であるとのべた.

平尾の発表に対しては, 岡林（大阪教育大）から訪 問治療に対する家族の拒否はなかったかと質問があっ た. 平尾はあったと答え，まず，親の受け入れ体制が 大切なので, 親子の抵抗をとり除くことから始め, 家 の外で会らこともあったと説明を加えた．東山（大阪 教育大）は, 訪問治療の場合, カゥンセリーのわく組 の中で治療が行われるので, カウンセリーから料金を とることが重要になると思われるがとのべた。これに 対しては，その必要を感じないとの答であった，黒橋 （神戸学院大）は (1) 登校拒否に限って訪問するのか, (2) カウンセラーを受け入れない子どもがカウンセ ラーを受け入れるように態度を変更する過程について の説明をもとめた（1)に対しては，非行問題の場合も ある. (2)については, 先ず, 親の承諾を得る.ケース によっては予告して出かけるが，予告なしに出かける こともある，その場合，会えても顔をみない，鍵をか けたりふとんにもぐり込んだりして出てこない等の抵 抗は大きいが, 誰かに受け入れてほしい気持があり,ア ンビバレントな状態を行動で示す．そのアンビバレン トの気持を受け入れることによってカウンセラーをう け入れるようになるとの説明があった. 越野（前揭） の訪問の際の人員及び職種についての質問に対して は, 子ども担当のものが 1 人. 時には親担当の相談員 も出かけるが別個に面接した. いずれの場合も心理士 がその任にあたったとの説明があった. 松原（筑波大） からは (1) 訪問面接は女性カウンセラーのみか男性 む いるのか, (2)特に高校生の男子の場合, 男性のカウン セラーの方が効果があるように思らがとの発言があっ た.これに対して，カウンセラーはすべて女性. どち らが効果的かは明言できないとの答えであった。

氏原の発表に対して, 東山（前掲）は，治療者は父親 像の役割は十分果たしているものの，治療者を friend として転移する感情を受け入れなかった.このことは, クライェントのboy friend との acting out と関連が あるのではないかと指摘した，氏原はこの点には気づ いていなかった.
岡林の発表に対して，橋口（東京家政大）は（1) 事例 と研究者の関わりはどらなっているか，(2) 治療者と は誰をさすのかと質問した.これに対しる答は (1) 研究 者は家庭教師のような形で㚐加した. (2)主治医, CP, $\mathrm{CW}$, 看讙婦であった. 越野 (前揭) の学校の担任教師 との連絡はどのようにしたかとの問いに対しては, 学 校との皘極的協力は得られなかったと答えた. 倉智(前 揭) は, SMT (School Morale Test) の結果から学校 環境の問題点を明らかにすることができたらよかった のではないかと示唆した. 平尾（都研）からの収容治 療の場合の親への援助，親との面接をどのようにした かとの問いに対しては, 症例 2 の場合, 祖母が家庭の 中心的存在で，母親は手伝い的存在であったため, 治 療者との関係はとりにくかったと答えた.

山内の発表に対して, 中原（前掲）は, 登校拒否の 原因の 1 つに親の側の問題があるとして, 治療者とし て親の側にかかわる限界はどこまであるか質問した。 これに対して, 親の側に問題意識をるたせ, 深めるこ とに限界を感じたと答えた。松原（前揭）は (1) 親の生 育過程とは親がどら子どもを生育したかといら意味 か, (2) 研究の今後の発展はどらなるのか質問した.こ れに対して (1) 親自身の生育過程である. (2) 具体的に 考えていないと答えた。

金子の発表に対して, 荻須 (聖徳短大)から (1)ごっこ 遊びやフィンガーペインテング等は症例児の他にどの ようなメンバーでなされたか，(2) 担任と発表者との 関係はどらであったかと問われた。これに対して (1) ク ラスの友人 1，2 名と症児の妹. '(2) 共同研究者の橋口 の指導のもとに治療していたので，担任との直接な関 わりはなかったと答えた. 山根（前揭）はRorschach Test の利用目的は何かと質問した。これについては共 同研究者の橋口から, 面接過程では言語化しにくかっ た内面の感情を表現するきっかけになって利用したと の説明があった.

\section{II ま と}

本部会での討論は学校カウンセラーの資格問題に焦 点があてられた. 兼任にしろ, 専任にしろ, カウンセ ラーを置いている学校はまだ多くない.しかしながら, その必要性は大きい，学校カウンセラー制度の設置が 叫ばれている昨今, 誰がカウンセラーの任にあたれる かとなると問題はさらに大きくなる．本学会でこの点 に関して早急に検討されるよう岡林からも要請があっ た.

（有田モト子・氐原 宽） 


\section{隐床・障害（840～847）}

座長 森 永 良子・神園 幸 郎

840 dearning Disabilities の意味

伊豆逓信病院 立川和子

841 Learning Disabilities

—LCT と書くことの障害—

伊豆逓信病院 森 永 良子

842 多義語連想検査法試案 (II)

一多義語連語にあらわれた防衛機制の研究一

京都大学 森 谷 寬 之

843 認知プロセッサの障害機構とその特性の解析

-1 記憶・検索機構の問題 -

筑波大学 神 園 幸 郎

844 認知プロセッサの障害機構とその特性の解析

-2 図形の preference とその生成機構 -

845 離人症の人間学的考察

東北大学 南 雲 直 二

立正女子大学 土 沼 雅 子

846 エンカウンターグループにおける集団力動の研

究

ードット法一

大阪教育大学 東 山 紘 久

\section{I 発表と討撞の経過}

本部門の報告は，各演題の内容に関連性がないため に，個々に質矤を行った，以下，その概略を述べる.

840 (立川) 中枢神経系の機能障害, あるいは発達的 な lag が原因と考えられる学習能力障害児 (LD) が, 日本でも決してすくなくないことについて，心理神経 学的検査結果より報告した. 神谷 (名城大学) は LD と MBD との関係，診断後のガイダンスの 2 点について 質問した。これに対して, MBD は原因論的な概念であ ク, LD は, 治療教育的な立場からの概念であり, MBD はLDの多くを占めていると述べた. ガイダンスは, 治 療教育の確立していない現状では，教師，親の受け入 れが大切であると答えた. 広田 (帝京大学耳犁科) は, 言語障害ならびに音声言語の習得と，学習能力障害の 関連について質問, 27 例中， 3 例に言語発達のおくれ がみられたと述べた。

841 (森永) は, 日本文字による言語性視覚障害の検 查の必要性から「かな」「漢字」によるLCT (Letter Completion Test)の試案を臨床の立場より提案した. 神谷は,「かな」の失点が高いことについて質問，これ
に対して，漢字はゲシュタルトとして形がとりやすい こと, 表音文字, 表意文字の差が「かな」の失点を高く していると回答した. またKey の出し方によって失点 が異なるのではないかとの質問には，当然予想出来る が、「かな」と「漢字」の失点の差には影響がないと思 うと回答した。

842 (森谷) は，同音多義語を刺激語とした．言語連 想検査の統計処理の結果を報告した. 多義性 (multiple meaning)に対する認知の度合を示す尺度は, 精神病群 が他の群より有意に小さく，不安，情緒的意味を含む 刺激数に対しては, 神経症群が敏感であることを指摘 し，ヒステリー，強迫神経症の事例を中心に，その具 体例を報告した。

843 (神園）は，情報処理の分野で用いられている反 応時間パラダイムを使って, 精神薄弱児の特性を分析 している.情報の処理で予想されるプロセスについて, モデルを設定し，そのプロセスにかかる負荷を変化さ せることによって出力とし，この反応時間から，逆に プロセスの特性を検討するという研究である. 結果は, 精神薄弱児における符合化のプロセスに欠陥があるこ とが指摘された．堅田（東京学芸大）より，目的は，

精神薄弱児の特性を解明することか，あるいは，モデ ルの検証か，の質問があり，精神薄弱児の特性を解明 することが目的であると述べた。

844 (南原) は, 手続として, 眓形材を呈示して,「好 き」「嫌い」を答えさせる preference の実験,ならびに 図形の角数に対する記憶検索, 困形の異同判断の実験 を用いて, preference の生成機構を発達的に検討して いる. 結論は, preferènce の生成は, affective な面の 影響は，変動要因として，作用するにすぎず，基礎と なっているのは，認知的な処理能力であることを指摘 した.

845 (土沼) は, 現象学的, 人間学的な治療上の立場 より，クライェントの存在様式を通じて，精神障害者 をふくめての, 人間一般の存在の本質的基本構造を探 ることが，症例研究の究極的目的であるとしている. 治療上の立場としては, 苦悩を共にし,「内的時空から の帰遷」の援助としている. 越野（浦和精神薄弱者更 生相談所）は, 超自我の強い personality では, 危機的 状況に駆りたててしまうのではないかと質問した。こ れに対して，共同存在性を基盤に，同一性を発見し， 同一性を不可分に自明性を求めるのであると答えた。

846 (東山) は,グループアプローチに打ける集団力 
動を測定し，グループにフィードバックすることによ ク，グループプロセスを促進させる方法として，ドッ ト法について報告した。 ドット法の測定の方法として の意味つけについて, 国分（東京理科大）からは, 座 標のタテ軸, ヨコ軸の意味づけ, 測定法としての分析 法について質問があり, 平尾（都立教育研究所）測定 法としての可否, など, 測定の tool としてのドット法 について討議が行われた。 これらに対して, 臨床の立 場からの提案であり, 自由に各自が意味を持たせて使 用するものであると答えた。 また，石井（日本大学大 学院）はドット法使用者の知的レベル, またその危険 性, 加藤（神奈川カウンセリングセンター）は, ドッ ト法使用の際のグループの構成, 経験回数について, 蓮見（日本大学）は, 使用する時期, 参加者がファシ リテーターに依存的になることはないか，など，使用 に際しての, 臨床面での問題点などについて論議がな された.

847 (木村) は, プレイセラピィにおいて. Cl.が th.
にどのよらな役割をもっているかが, 治療をすすめ てゆく上で重要であるという立場から, th. が Cl. か ら，治療場面でどのようによばれるかを，事例を中心 に考察を行っている.この演題については, 治療場面 でのよびかけ，治療中によびかけが変化してゆくこと と, $\mathrm{Cl}$.の変化など, 討議が行われた. 東山は, $\mathrm{Cl}$.の よびかけは特に問題ではなく, th.の自覚が問題ではな いかなど意見が出された。

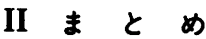

本部門の研究は, 障害児研究の方法論に関する演題 3 題, 臨床検查の試案 2 題, 症例研究を主にした 2 演 題, エンカゥンターグループの研究 1 題と, 内容がき わめて多岐にわたり各演題の共通性が低く，討議を発 表させることが困難であった.

今回の発表は，いずれる継続して研究が展開される ものであり, 今後の研究成果に期待したい.

\section{臨床・障害（848～854）}

座長黒橋 夈一・緑川尚夫

848 850 都内公立教育相談室の実態

東京都立教育研究所

$\begin{array}{lll}\text { " } & \text { 佐 賀 明子 } \\ \text { " } & \text { 平 田 慶 子 } \\ \text { " } & \text { 永 瀬 純 三 } \\ \text { " } & \text { 岩 村 由美子 }\end{array}$

851 学校における相談に関する研究(1)

一高校生の相談に対する態度とその要因につい $\tau-$

関東学院高等学校 橋 本 幸 明

852 Peer Counseling の展開と問題点 神戸学院大学 黒 橋 条一

853 障害幼児における心理療法的アプローチの機能と 特徵 $(V)$

淑徳大学 counseling-Center 宇佐川

浩

854 Role Pleying に扣ける「成長」の一考察

一A の case を中心に一

越谷保育専門学校 高 橋 泰子

\section{I 発表と討論の経過}

緑川（848）佐賀（849）平田（850）らは "東京都に おける教育相談体制のあり方”研究の一環である「都 内公立教育相談室の実態調查」の結果を発表した，都 内 50 の公立相談室の現状と問題点を全都的視野に 立って，子ども(4才〜15才)人口との関連で分析・考 察したものである.

橋本 (851) は高校生の相談に対する態度とその要因 について, 自校 2 年生を対象に質問紙法による調査を 行い，その結果の分析・考察を発表した．相談に対す る生徒の肯定的態度は有効な相談室活動と相談室の周 知度が重要な要因であると指摘した。

黒橋（852）は自校におけるClub としての counseling 研究会が行った「新入生のための学友 counseling」 について報告, 次いで Peer Counseling の可能性と有 効性及びその問題点を提起した.

宇佐川（853）は精神発達遅滞の幼児に対して遊戯療 法, 音楽療法, 絵画療法, 運動療法, モンテッソーリ 法, 親子療法等を組合わせて実施し, その結果の評価・ 分析を通して各療法の持つ機能と特徵を明らかにし, 同時に子どもの状態に即して各療法を用いることの重 要性を提起した. 
高橋 (854) は職場で同僚や先輩とうまくいかない21 才の保母が, Role Play の体験を通して人格変容に至 る過程を分析・考察し, Role Play が治療の方法や場 になり得ると提起した。

〈848～850〉に対して：黒橋（神戸学院大）は（1) 非 常勤相談員の処遇について, 堀（日本福祉大）は (2) 専門家の協働性が各相談室で制度化されているか, 加 藤（神奈川カウンセリング協会）は (3) 相談担当者は 心理専門か教職員の兼任か，その是否について，有田

（関東学院高校）は (4) 相談の潜在対象児の把握方法 及びその対象児をどんな手だてで相談室に結びつける か等，提案も含めて質問をした．演者からはそれぞれ についての補足説明があり,特に (2)については本研究 のねらいの1つであり, 各相談室のみではなく, 相談 機関相互の協動性の確立が今後の課題であること, (3) については相談の多様性や専門的協動性から一方に偏 することは問題である等の回答があった.

〈851〉に対して：岩村（都研）は (1) 来談者の数と 内容について, 永瀬（都研）は (2) 生徒に対する相談 のための時間的配慮の実状, (3) 当校における教育相 談の機能及び (4) 生徒指導部との関連等について質問 をした. 演者からは実態の補足説明がされ，特に (3)に ついては専門機関との関連から本校では談話室的機能 で可と考えると回答された。な扰平田（都研）から教 育相談が比較的遅れている学校で本調査と同じような 調查の実施が要望された。

〈852〉に対して：橋本（職業研究所）は (1) 来談者 数の 50 年度減少の理由, (2) 入学時の相談内容の Club 問題, さらに (3) 本実践の “五月危機” への影響 等について, 島崎（上智大）は (4) 本実践と学生相談 との関係，(5) Club-Member $の$ counseling 資質や訓 練の問題, (6) Peer Counseling の役割を member 自 身どうとらえているか等について質問をした，演者か らそれぞれ補足説明がなされ，特に (4) (5) (6)について 学生相談担当が club 顧問であり, club 活動の長短を 検討し, 個別指導を加えて積極的援助をしていること, (3)については現在未検討である等の回答がなされた。

〈853〉に対して：佐藤（愛知大）は (1) 遊戯療法の 遊戲の中での可変性, 柔軟性, (2) 対象児の選び方, (3)
演者の治療教育の考え方等について, 松本（職研）は (4) Therapist の技倆の問題と (5) 自己評価の問題に ついて, 提言も含めて質問をした. 演者からは (1)の指 摘を認めながらも遊具の未整理が問題となること, (2) については (1) との関連で検討を今後重ねること, (3) は心理療法の中で診断的, 教育的アプローチ（学習的 側面へのかかわり）をすることと考える等の回答がな された. また (4) (5) については，実習者に対する control, case study, 観察評価を行い, 質的向上を図ってい る. Therapist 自身の自己評価は今後の課題としたい との回答がなされた.

〈854〉に対して：荻須（聖徳短大）は (1) A のRole Play 研究会加入の動機, (2) Role Play の場の設定法 について, 岩村 (都研) は (3) 事例 2 の A の役割から 考えると counseling ではないか, (4) A の体験過程 1 〜 5 段階はどの Role Play の session でも可能か, (5) Role Play は問題解決に counseling に優るといえ るか等, 松本 (職研) は (6) A の事例は労働不適応で はないか, Role Play に限界はないか, 平田（都研）は (7) 保育所の対人関係の実態から, 養成機関としての follow up の必要性等, それぞれ提案を含めた質問を した. 演者からそれぞれに補足説明がなされ，特に(6) については, 保育の現状から適正就職のみで保母の不 適応の解決は困難, 保母養成機関としては職場の現状 での適応を図る努力をしたいと述べられ，平田の提言 と結論的に一致した.

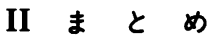

本部門の参加者は 20 余名, しかもその出入りが多 かったのは残念であった。これは発表主題が多岐にわ たり，参加者の関心が必ずしも発表内容に対応しにく かったのではないかと思われた，そのため，質疑応答 が活発なわりに討論が深められなかった，発表主題の 組合わせは短時間の討論の焦点化, 効率化のためにも 今後一層の工夫が望まれた。しかし総体的には, 各研 究がそれぞれ個性的で, 特に教育相談推進にかかわる 研究は今後に期するところ大であった.

（黒橋条一，緑川尚夫） 


\section{臨床・障害（855～862）}

座長江口法子・冨安芳和

855 施設精神薄弱児の集団遊歔治療に関する研究

-1 . 研究の概要と治療過程一

仏教大学心理学研究所 (1) 口江 法子

(2) 渡 辺文子

$856-2$. 遊歔治療集団の相互作用過程の分析一 仏教大学心理学研究所 (3)鉾 石 三枝子

857 -3. 治療前後の対象児の日常生活場面におけ る行動変化の検討一

仏教大学心理学研究所 園 原太 郎

$858-4$. 実験的観察場面に打ける遊戯行動の

変化一

\begin{tabular}{|c|c|c|c|}
\hline 大学心理学研究所 & 橋 & 本 & 順 \\
\hline " & 杉 & 田 & 千倠 \\
\hline "I & 浪 & 花 & \\
\hline "I & 加 & 藤 & 章 \\
\hline
\end{tabular}

859 精神遅滞者施設におけるケアのパターンに関す

る研究

一III 結果の分析（その 1)一

愛知県コロニ一発達障害研究所

(1)富 安 芳 和

"

(2)小 塩 允 護

860 -III 結果の分析 (その 2)-

愛知県コロニー発達障害研究所 三宅信 一 861 “障害幼児の(母)親指導の試み”

一その 2-

東京都心身障害者福祉センター ○鎌 田 文 聰 " 高畑隆

862 母親の障害児に対する態度の変容

国立特殊教育総合研究所 位 頭 義 保

\section{I 発衰と时論の概要}

この分科会では, 江口 (855), 渡辺 (856), 鈝石 (857) および杉野 (858) ら9 名の施設収容精神薄弱児 3 名を 対象にした集団遊戯治療に関する共同研究, 冨安 (859) と小塩 (860) らの精神遅滞者収容施設におけるケア・ パターンに関する共同研究, 鎌田 (861) らと, 位頭 (862) の障害児をもつ親のカウンセリングに関する研究 2 題, 計 4 研究が, 上記のプログラムに従って発表され た. これら 4 研究個々の発表後に, フロアーの参加者 と発表者との間で，若干の質疑応答が行われたのみな らず, 全研究発表終了後に, かなりの活発な討論の展
開がみられた。総会最終日の午前とはいえ，ほぼ35名 の参加者があった.ここでは，それぞれの研究毎に， 質疑応答と討論とを合わせ，その経過の概要を記すこ とにする.

江口 (855), 渡边 (856), 鋳石 (857), 杉野 (858) らの一連の共同研究に対して, 若葉（東学大）が, 2 か 月間 10 回の治療を行っている治療回数決定の根拠, 三 浦 (北療育園) が 1 回の治療時間を 45 分とした理由を 質したのに応え，江口らは，治療の場が施設内に仮説 されたものであり，施設側の年間スケジュールによる 制約, および, 10 回ないし 15 回でグループの再編成を 行うことなどを挙げた．また，渡辺（856）に対し，対 象児の行動変化を評定するための行動群の選定の仕 方，鈗石（857）に対し，遊歔療法で生ずる根本的な情 緒面の変化についての評定の手続に関する質問が若葉 （東学大）からあった．さらに, 10 回にわたる治療経 過に打いて，必ずしも望ましくない行動変化を示して いる対象児がいることに関して，三浦（北㞠育園）か ら、アフター・ケアの必要性が述べられた。

富安 (859) と小塩 (860) の発表に対して, 小川（北 療育園) から，公立施設と私立施設との間でのケア・ パターンに拈ける差異の存否についての質問があり, 冨安は，前者の質問には固有名詞を付して結果を公表 すべきでないこと，後者に対しては，現在のところ， resident oriented パターンが望ましいと思われるが, 終局的には収容児(者)の適応行動の発達との関連で決 められるべきだと答えた。 また，三浦（北療育園） から, 調査結果を“なま”の形で公表した方がノーマ リゼーションを進める実践者の側にとって役に立つと の意見があった.

鎌田（961）の発表に, 三浦（北療育園）が, 親の力 ウンセリングの過程で, 親の側にカッターストローフ な側面（離婚，自殺企図等）が出現することに対する 備えについて質したのに，鎌田は，そうしたケースが 今まで現実になかったこと，来所者のうち説明後希望 した者を被指導グループに組んでいること，問題が起 こりそうな時には，母親指導の中で，治療者やほかの 親が援助にまわること，時には，個別相談に切り換え たり，電話連絡に応じて出張指導をするなどを試みて いる旨述べた．また，並行して行われる子どるの遊 戯療法に拈いて治療者がローテイトされていることに ついて, 被治療者と治療者との間に治療に伴なって深 まるポールの観点から，若葉（東学大）によって疑問 
が提出された。

位頭 (862) の発表に関して, 越野 (浦和精薄更生相) から, 親の態度変容が, カウンセリングの効果といら よりは，子どもの噇害が重いことからくる諦めによる 親の精神的安定の結果ではないかという質問がなげか けられた。 また，若葉（東学大）からは，母親の行動 分析が 1 回の VTR 録画をもとに行われている点につ いて，方法論上の疑問が投げられた。

\section{II と め}

この分科会に発表された 4 つの研究は, テーマこそ 異なっていたが，すべてが障害児やその親の治療，ヶ ア，カウンセリングなどの実践をその内容とし，その 研究法として，観察評定法を用いたことに共通性があ
り，個々の研究についての討論が，他の研究に深い関 連性をもつことになった。

後者の観察評定法については，その信頼性を高める ために, 観察者の選定〔若葉（東学大），観察者の訓 練〔冨安 (愛知コロニー) ), 観察評定項目の精練〔杉 田（仏教大）〕の重要性が論じられたし, 前者の問題に ついては, 治療, ケフ, カウンセリングのあり方が, 対象児(者)の発達とか適応上の変化といった実践上の 価値との関連で，たとえば，江口らの研究 $(855,856$, 857，858）に対する「治療回数」「「フター・ケア」の 問題, 鎌田らの研究（861）に対する「危機的状況への 配虑」, 冨安らの研究 $(859,860)$ に対する「施設改善 の方向性」などについて論じられたのである.

（富安芳和・汇口法子）

\section{臨床・障害（863～868）}

座長 藤 田 和 弘・藤 本 光 孝

863 小児切断者に関する研究 (2)

一母親の切断受容一

東京都補装具研究所 ○浪 江 久美子 東京学芸大学 八 野 正 男

864 肢体不自由児病室におけるーグループの最適数

について 1. 大, 小, 集団の比較

一オヤツ場面に観察された発言量から一

東京都立北療育園 三 浦 勝 雄

865 脳性まひ幼児の縦断的発達研究

一社会的発達について一

筑波大学 藤 田 和 弘

866 脳性まひ児特に痤直型児の知能構造と周産期異 常

東京都立北療育園 小川 義 博

867 精神薄弱児の運動反応に及ぼす言語の効果 (2) 香川大学 藤 本 光 孝

868 障害幼児の動作系ラテラリティ

$$
\text { 京都大学 大 井 学 }
$$

\section{I 讨諞の経迥}

浪江 (863) の発表について共同研究者の八野（東京 学大）から次のような補足説明があった．1）小児切断 児をもつ母親の来談が子どもの出生後かなりの期間を おいて (1 年或いはそれ以上, 就園・就学期近くになっ て）からであること，2）対象児数が少ないのに加え，
切断の部位, 程度に応じて母親の受容のあり方に偏差 があること，3）対象児が幼児であるため切断受容につ いて直接対象児からの資料収集が困難であること．今 後, 母親のパーソナリティ及び切断実態，母子の交互 作用等をふまえ，事例研究による接近を考えているこ と. 藤本（香川大）は母親の年齢は切断受容に影響す ると考えられるが，その点の分析はどうか，藤田（筑 波大）は障害の過大・過小評価の基準は何か，障害受 容の定義またはそれを把える方法論を質問した，浪江 は，母親の年龄は吟味していないが，概ね 30 歳前後で あること, 評価基準は共同研究者らの印象によったも ので統計的に検討したものでないこと，障害受容とは 親が子どもの能力を客観的に評価していることをもっ てあてていること, 親のかかえている問題の本質に迫 る手段の $1 つ と し て 今$ 後事例研究を考えていることの 回答があった。

三浦 (864) の発表について三浦から肢体不自由児病 室における集団の最適規模についての理論的根拠に関 連する発表があった．それをめぐって小集団の力動に ついての研究を参考にしてはといら意見もあったが， 方法論についての質問や意見に移行した．藤本は病室 における療育活動をすすめる場合，集団規模について の研究の意義を認めながら，方法論として特定の場面 に拈ける子どもの発言量を測度とすることに問題があ ク，むしろ様々な療育活動での子どもの活動を多面的 にみていく必要があるのではないかと質問した．それ に対し，オヤツ場面を指導しやすくすることも研究目 
的の 1 つであるが, 病室の規模が幼少長期入園児に及 ぼす影響を明らかにしたい旨の回答があった。藤田は 病室における集団の最適規模を研究する意義について 質問した三浦は病室とは幼少長期入園児の生活のべー スとなる場であり，その場は「1 人が全員に影響を与 え，全員もその 1 人に影響を与光得る」ような場であ る必要がある。そのような影響を明らかにすることに 意義があるとした。八野は大集団の病室に参加する職 員数について質問した，大集団については，その時点 で勤務して参加可能な職員全員があたり，定数ではな い旨の回答があった. 大井（京都大）は集団の規模は 療育指導の場面，条件，目的等によって变わるもので ある．被験者をDA で統制したり，子どもの交互作用 を多様にする場面設定を考光研究をすすめてはどうか と提言があった。

藤田（865）の発表に，木村（群馬大）から，社会制 というものは母-子, 教師-生徒, セラピストークライェ ントといらような相互補完的なものである。そのよう な相互補完性を考虑した上で個人の特性としての社会 性発達の度合が判定されたかどらかの質問があった。 それに対し藤田は，そのような考方方を認めながら， 今回の発表は綎断的に発達検査を実施した結果の社会 性発達に限定したものである旨の回答があった. 小川 (866) の発表に対し，木村からラテラリティ（左 マヒ，右マヒ）が考えられたかどらか，また，これと IQ (VIQ, PIQ) との関係が検討されたかどうか質問が あった. それに対する小川の回答は，今回の研究の対 象児の中に片マヒは含まれていないためラテラリティ とIQ との関係は検討されてなかったが，今後この点 に関して検討する必要性があると答えた，藤田は脳性 まひ児の知能に及ぼす要因には周産期異常など一次的 要因に加えて環境（二次的）要因も重要であり，今後 の方向としては明らかにされた一次的要因を統制変数 としてどのような二次的要因が脳性まひ幼児の知能に
大きく影響するのかを研究の視点にしていく必要があ りはしないか, その前段階として周産期異常といら要 因の検討を位置づけるべきではないかと指摘した。こ れに対し小川はそらした方向で考えていきたいと答え た. 藤本は知能構造を相関行列で検討する際, 周産期 障害別の相関行列で検討してはどうかと提言した.

藤本 (867) の発表に大井から被験者の DA について 質問があったが, 被験者の DA はCA をやや下まわ る.しかし DA は本研究とは直接的な意味をもたない と考えている旨回答があった。ささらに大井は討議希望 事項にふれ，比較的疲労の加わりにくい課題として直 立行動を用いてはどらかと提言があった。

大井（868）の発表に対し小川（都立北療育園）から 使用された課題について質問があった．1）丸棒插入 動作反復課題を用いた理由，5）描画課題での測度を 用いた理由である.大井は 1) 単なる reaching test で は被験者の motivation が高まらないこと, この動作 は 1 歳 2 歳の幼児に等しく遂行可能であることが理 由である. 2) 描画課題での判定の時点がペンのもち かえ直後としているのは，一定の運動的な構えが既に 非対称的に形成されている（或いはその時点で一側化 している）か否かをみるためであると回答した。 それ に対して小川は知覚障害のある幼児が含まれている場 合,一定時間のペンのもちかえ行動をチェックする方 法を考える必要があるので質問したと述べた。

\section{II $ま$}

本分科会の 6 発表は研究対象では共通項のあるもの ああるが，方法論は多様である，そのため討論は個 々 の発表に対する質問や意見とそれに対する応答の形式 となった. 総会最終日の午後の発表といらこともあっ てか少人数での討論となったが，それがかえって方 法論についてかなり活発なそして建設的な討論となっ たように思われる.

（藤田和弘・藤本光孝） 